\title{
ANALISIS KEBAHASAAN PADA ARSIP SURAT MTS ASH SHIDDIQIYYAH KABUPATEN CIREBON
}

\author{
Shofuroh $^{1}$, Tati Sri Uswati², Indrya Mulyaningsih ${ }^{3}$ \\ Fakultas Tarbiyah dan Keguruan, IAIN Syekh Nurjati Cirebon \\ lemail: shofuroh17@gmail.com, ${ }^{2}$ email: tatisriuswati@gmail.com, ${ }^{3}$ email: indrya.m@gmail.com
}

\begin{abstract}
Abstrak
Penelitian ini bertujuan untuk mengeksplanasikan bentuk-bentuk kebahasaan yang terdapat pada arsip surat dinas MTs Ash Shiddiqiyyah Kabupaten Cirebon. Penelitian ini merupakan penelitian kualitaif deskriptif. Metode pengumpulan data pada penelitian ini menggunakan teknik pusaka. Sumber data yang digunakan dalam penelitian ini berupa dokumen resmi berupa arsip surat dinas MTs Ash Shiddiqiyyah Kabupaten Cirebon. Teknik yang digunakan adalah analisis isi yang dilakukan secara interaktif melalui tiga kegiatan. yaitu pengumpulan data, reduksi data, penyajian data, penarikan kesimpulan dan verifikasi. Hasil penelitian ini menunjukkan bahwa: bentukbentuk kebahasaan masih kurang tepat, dari 20 data sejumlah 15 kesalahan penulisan kata yang tidak baku, enam kesalahan penulisan kata/frasa yang seharusnya dirangkai/ dipisah, kesalahan penggunaan tanda baca (9 tanda garis miring, satu tanda seru, 12 tanda koma, dan 13 tanda titik), 25 kesalahan penggunaan huruf miring dan huruf tebal, dan 38 kesalahan penggunaan huruf kapital.
\end{abstract}

Kata Kunci: kebahasaan, kesalahan, kata, penggunaan.

\begin{abstract}
This research aims to export the forms of the linguistic in the archives of the Ministry of Letters MTs Ash Shiddiqiyyah Cirebon Regency. This research is a descriptive quality research. The method of collecting data on this research uses heirloom techniques. The source of the data used in this study is an official document in the form of archive letter from MTs Ash Shiddiqiyyah Cirebon Regency. The technique used is the analysis of content performed interactively through three activities. i.e. data collection, data reduction, data presentation, withdrawal of conclusions and verification. The results of this study show that: the linguistic forms are still less precise, there are 15 words that are not raw, six words of writing/phrases that should be assembled/divided, the use of punctuation errors (9 slash marks, An exclamation mark, 12 semicolons, and 13 dots), 25 errors using italics and bold letters, and 38 error capitalisation.
\end{abstract}

Keywords: the language, the error, the word, the use.

\section{PENDAHULUAN}

Bahasa Indonesia merupakan bahasa negara seperti yang disebutkan dalam UndangUndang Dasar 1945 bab XV, pasal 36. Sesuai dengan kedudukannya sebagai bahasa negara, bahasa Indonesia dipakai dalam setiap situasi formal baik secara lisan maupun tulisan (Alex \& Achmad, 2011). Surat dinas dibuat untuk memberikan informasi terkait persoalan-persoalan yang bersifat resmi sehingga pemakaian bahasa Indonesia yang baik dan benar sudah semestinya diterapkan. 
Surat-menyurat dijadikan sebagai media komunikasi tulis yang efisien dan efektif dalam aktivitas suatu instansi atau lembaga karena melalui surat penyampaian informasi akan lebih mengena dan terpercaya. Oleh sebab itu, surat digunakan hingga era modern seperti sekarang. Surat merupakan suatu sarana komunikasi dalam bentuk tulisan yang digunakan untuk menyampaikan informasi atau gagasan dari satu pihak kepada pihak lain (Nadia \& Sugihastuti, 2018).

Pada penulisan surat dinas tentu terdapat aturan atau kaidah yang harus diterapkan dalam pembuatan surat. Kaidah dalam menulis surat antara lain penggunaan bahasa surat. Sering kali dalam penulisan surat dinas masih terdapat kesalahan penggunaan kebahasaan. Tidak sedikit lembaga yang kurang memperhatikan penulisan surat sesuai aturan atau kaidah. Kesalahan sebanyak 1161 data telah ditemukan pada surat dinas, kesalahan tersebut antara lain penggunaan ejaan, pilihan kata, dan kalimat efektif. Selain kesalahan ejaan ditemukan kesalahan penggunaan kata yang tidak baku, ketidakcermatan kata, dan ketidaksantunan kata (Yolanda, 2017). Berdasarkan hasil pengamatan, kegiatan administrasi di salah satu lembaga juga tidak sedikit surat yang masih kurang memperhatikan penulisan surat yang baik dan benar.

Menurut Hastuti (dalam Darmastuti, 2009) maksud surat yang kurang akan mengakibatkan berbagai hal negatif, diantaranya: (1) penerima surat sulit memahami isinya, (2) jawaban yang dikehendaki oleh pembaca/penerima surat tidak seperti yang dikehendaki oleh penulis/pengirim surat, dan (3) isi surat dapat dianggap meragukan bagi penerima surat. Hal tersebut sebisa mungkin untuk dihindari karena kesalahan berbahasa dapat menjadikan informasi yang disampaikan akan kurang dipahami dengan baik oleh pihak penerima surat, maka perlu ketelitian kembali saat membuat surat dinas.

Bagi orang awam untuk membuat surat dinas yang baik dan benar tidak cukup mudah, kecuali orang-orang tertentu yang memang sudah mengkaji perihal persuratan. Bagi para pegawai di lembaga pendidikan pada bagian administrasi sekolah, persuratan bukan lagi menjadi hal yang asing karena segala kegiatan pengadministrasian dicantumkan dalam surat. Namun, pada praktiknya permasalahan kebahasaan dan sistematika penulisan surat masih menjadi persoalan yang sering dijumpai dalam surat dinas.

\section{Tinjauan Pustaka \\ Surat Dinas}

\section{Pengertian Surat Dinas}

Menurut Nadia \& Sugihastuti (2018), surat merupakan salah satu sarana komunikasi tertulis yang digunakan untuk menyampaikan suatu informasi atau gagasan dari satu pihak kepada pihak lain. surat dinas ialah surat yang isi gagasannya mengenai masalah-masalah kedinasan (Darma \& Kosasih, 2012). Surat ditinjau dari segi isi adalah jenis karangan (komposisi) paparan. Di dalam paparan pengarang menyatakan maksud dan tujuannya serta menjelaskan hal yang dipikirkan dan dirasakan, sedangkan ditinjau dari wujud peraturannya, surat adalah bentuk percakapan tertulis. Jika ditinjau dari fungsinya, surat yaitu suatu alat komunikasi tertulis (Soedjito, 2018).

Slamet Triyana (dalam Wijaya, 2016) menyatakan bahwa surat adalah satu sarana komunikasi tertulis untuk menyampaikan pesan atau informasi dari satu pihak (orang, instansi atau organisasi) kepada pihak lain (orang, instansi atau organisasi). Surat yang ditulis atau dibuat oleh seseorang dan isinya menyangkut kepentingan, masalah, dan persoalan-persoalan. 
Berdasarkan berbagai pendapat di atas disimpulkan bahwa surat dinas adalah sebuah alat komunikasi berupa pemaparan dalam bentuk tulisan yang berisi penyampaian informasi atau gagasan tentang permasalahan formal atau resmi yang dibuat oleh satu pihak kepada pihak lain (orang, instansi, atau organisasi). Adapun penulisan surat dinas harus ditulis secara jelas, singkat, dan memperhatikan kaidah penulisan surat dinas.

2. Ciri-ciri Bahasa Surat Dinas

Bahasa surat dinas memiliki ciri-ciri sebagai berikut.

a. Bahasa Baku

Bahasa baku ialah bahasa yang sesuai dengan kaidah yang sudah dilazimkan (Soedjito, 2018). Bahasa baku menurut Suprapto (2014) adalah bahasa yang sudah diakui kebenarannya menurut kaidah yang telah dilazimkan. Adapun menurut Darma \& Kosasih (2012) bahasa baku ialah ragam bahasa yang penulisan maupun pengucapannya sesuai dengan kaidah yang dibakukan. Bahasa baku yang digunakan dalam surat dinas mencerminkan keresmian dan kewibawaan. Bahasa baku pada surat dinas yaitu bahasa yang tidak dipengaruhi oleh bahasa daerah maupun bahasa asing, tidak rancu dan tidak mengandung arti pleonasme (pemakaian kata-kata yang berlebihan).

b. Bahasa Efektif

Menurut Harumi (2011) bahasa yang dipakai dalam surat dinas hendaknya sesuai dengan kaidah, efektif, efisien, dan lugas. Sedangkan menurut Soedjito, (2018) bahasa yang efektif ialah bahasa yang diungkapkan secara tepat dan mencapai sasaran. Pemakaian bahasa yang efektif dapat diketahui dengan pemakaian bahasa yang sederhana/lazim, ringkas (tegas dan mudah dipahami, jelas/tidak berbelitbelit (tidak menimbulkan kesalahpahaman), sopan/tertib dengan takzim, dan menarik.

Menurut Pujiyono (2013) kalimat efektif adalah kalimat yang dapat mencapai sasarannya dengan sesuai secara baik sebagai alat komunikasi. Adapun menurut Junaedi (2015: 53) kalimat efektif ialah kalimat yang memerhatikan proses penyampaian dan proses penerimaan kepada pembaca yang berlangsung dengan baik, dapat diartikan pula bahwa kalimat efektif merupakan kalimat yang mewakili pikiran penulis secara tepat.

Berdasarkan berbagai pendapat di atas dapat disimpulkan bahwa bahasa efektif ialah ide/gagasan yang diungkapkan oleh komunikator dengan bahasa yang sesuai dengan kaidah, efektif, efisien, dan lugas dan diterima oleh komunikan secara baik dan tepat.

3. Kaidah Ejaan Bahasa Indonesia

Menurut Finoza (dalam Yulianto, 2016) Ejaan ialah seperangkat aturan tentang cara menuliskan bahasa dengan sarana huruf, kata, dan tanda baca. Kaidah ejaan bahasa Indonesia berdasarkan pedoman umum (dalam Redaksi Cemerlang, 2018) antara lain sebagai berikut.

a. Penulisan Kata

Penulisan kata dasar dituliskan secara satu kesatuan.

Contoh: Dokumen itu sangat tipis.

b. Kata Berimbuhan 
Imbuhan (prefiks, infiks, sufiks, konfiks) ditulis dengan cara dirangkai dengan bentuk kata dasarnya.

Contoh: Bermanfaat, Memudahkan

c. Kata Depan

Beberapa kata depan seperti di, dari, ke, ditulis terpisah dari kata yang mengikuti.

Contoh:

Ruang kelas VII berada di sebelah timur.

Buku di atas meja.

Saya pergi ke ruang guru.

Nilai tersebut berasal dari ulangan harian.

d. Singkatan dan Akronim

Penulisan nama orang, gelar, pangkat, atau jabatan diikuti dengan tanda titik pada setiap unsur singkatan tersebut.

Contoh:

Sdr. saudara

S.Pd. sarjana pendidikan

S.Kom. sarjana komunikasi

Penulisan nama lembaga pendidikan, pemerintah, organisasi, serta nama dokumen resmi ditulis dengan huruf awal setiap kata menggunakan huruf kapital. Contoh:

SMP Sekolah Menengah Pertama

Penulisan singkatan yang terdiri atas tiga huruf atau lebih ditulis diikuti dengan tanda titik.

Contoh:

dsb. dan sebagainya

dll. dan lain-lain

Penulisan singkatan yang lazim dipakai terdiri atas dua huruf dalam suratmenyurat diikuti dengan tanda titik.

Contoh:

s.d. sampai dengan

a.n. atas nama

e. Tanda Baca

Penggunaan tanda baca dalam setiap tulisan merupakan hal yang perlu diperhatikan begitu juga dalam penulisan surat pemakaian tanda baca harus dicermati. Tanda baca yang banyak dipakai dalam persuratan, yaitu tanda titik (dipakai pada akhir kalimat yang bukan seruan atau pertanyaan, digunakan pada akhir singkatan nama orang, gelar, jabatan, pangkat, dan sapaan, dipakai pada singkatan kata atau ungkapan yang sudah sangat umum, dipakai untuk memisahkan angka jam, menit, dan detik yang menunjukkan waktu, dipakai antara nama penulis, judul tulisan, tempat terbit, dan daftar pustaka, dipakai untuk memisahkan bilangan kelipatan). (Putrayasa, 2007)

Tanda koma (,) (dipakai di antara unsur-unsur dalam suatu pembilangan atau perincian, dipakai untuk memisahkan kalimat setara yang satu dari kalimat setara berikutnya, dipakai untuk memisahkan anak kalimat dari induk kalimat apabila anak kalimat mendahului induk kalimat, dipakai dibelakang kata atau ungkapan penghubung antarkalimat yang terdapat di awal kalimat, dipakai untuk memisahkan petikan langsung bagian lain dalam suatu kalimat, dipakai diantara penulisan nama dan alamat, bagian-bagian alamat, tempat dan tanggal, dan nama 
tempat yang ditulis berurutan, dipakai untuk memisahkan bagian nama yang susunannnya dibalik dalam daftar pustaka, dipakai di antara bagian-bagian dalam penulisan catatatan kaki, dipakai di antara nama orang dan gelar akademik yang mengikutinya).

Tanda titik koma (;) (dapat digunakan untuk memisahkan kalimat setara dalam suatu kalimat majemuk sebagai pengganti kata penghubung, juga dapat dipakai pada rincian ke bawah yang unsur-unsurnya berupa kelompok kata). Tanda titik dua (:) (digunkan pada akhir suatu pernyataan lengkap jika diikuti rangkaian atau pemerian, digunakan sesudah kata atau ungkapan yang memerlukan pemerian, dipakai di antara nomor dan halaman, di antara judul dan anak judul suatu karanga, serta nama kota dan penerbit buku dalam karangan). Tanda hubung (-) (menyambungkan suku-suku kata dasar yang terpisah oleh pergantian baris, menyambungkan awalan dengan bagian kata dibelakangnya, menyembungkan unsur-unsur kata ulang, menyambungkan huruf kata yang dieja satu persatu, dan bagian-bagian tanggal, dipakai untuk merengkaikan partikel sedengan kata berikutnya dimulai dengan huruf kapital, ke- dengan angka, angka dengan -an, singkatan berhuruf capital dengan kata/imbuhan, dan nama jabatan, digunakan untuk merangkaikan unsur bahasa Indonesia dengan unsur bahasa asing). Tanda garis miring (/) (dipakai di dalam nomor surat dan nomor pada alamat, serta penandaan masa satu tahun yang terbagi dalam dua tahun takwin, dipakai sebagai pengganti kata dan, tiap) (Alex \& Achmad, 2011: 299-316).

\section{METODE PENELITIAN}

Pendekatan penelitian ini adalah penelitian kualitatif. Menurut Moleong (2013: 6) penelitian kualitatif adalah penelitian yang bertujuan untuk memahami fenomena subjek penelitian misalnya, persepsi, perilaku, tindakan, motivasi dan lain-lain melalui cara deskriptif dalam bentuk kata-kata dengan memanfaatkan berbagai metode alamiah. Menurut Sukardi (dalam Yolanda, 2017) penelitian deskriptif dilakukan untuk menggambarkan objek atau subjek yang diteliti secara sistematis sesuai dengan karakteristik dengan cepat.

Penelitian ini akan menghasilkan data berupa kata-kata/kalimat tertulis untuk mengeksplanasikan secara detail ketidaktepatan bentuk-bentuk kebahasaan pada arsip surat MTs Ash Shiddiqiyah kabupaten Cirebon. Dengan demikian jenis penelitian ini adalah penelitian kualitatif deskriptif.

Sumber data pada penelitian ini, yaitu berupa dokumen arsip surat MTs Ash Shiddiqiyyah Kabupaten Cirebon. Jenis dokumen dapat dikategorikan sebagai dokumen pribadi, resmi, dan budaya popular (Emzir,2012). Arsip surat termasuk dokumen tertulis yang bersifat resmi. Sesuai dengan karakteristik penelitian kualitatif ini bersifat deskriptif. Data deskriptif yang akan terkumpul berbentuk kata-kata atau gambar (Emzir, 2012). Arsip surat MTs Ash Shiddiqiyyah kabupaten Cirebon yang akan digunakan sebagai bahan penelitian yaitu arsip surat masuk dan surat keluar bulan Oktober s.d. Desember 2018.

Adapun metode yang digunakan dalam pengumpulan data adalah dengan teknik pustaka. Menurut Subroto (dalam Sunarti, 2011) teknik pustaka adalah teknik pengumpulan data dengan menggunakan sumber tertulis untuk memperoleh data sebagai bahan penelitian. Data yang akan dikumpulkan, yaitu arsip surat masuk dan keluar MTs Ash Shiddiqiyyah kabupaten Cirebon, akan dibaca, dipahami bentuk-bentuk kebahasan dan sistematika penulisan surat yang digunakan kemudian dianalisis kesalahan yang 
terdapat pada beberapa surat dinas tersebut. Sebelum menganalisis terlebih dahulu memberi nomor pada setiap surat berupa data 1 , data 2 , data 3 , dan seterusnya hingga data terakhir dan instrumen pengumpulan data penelitian ini yaitu peneliti sendiri yang akan melakukan penelitian untuk memperoleh data. Moleong (2013: 168) menyatakan kedudukan peneliti dalam penelitian kualitatif sebagai perencana, pelaksana, pengumpul data, penganalisis, penafsir data, sehingga pada akhirnya peneliti menjadi pelapor hasil penelitian yang dilakukan.

Teknik analisis data pada penelitian ini, yaitu analisis isi. Menurut Neoendrorf (dalam Emzir, 2012) analisis isi adalah suatu analisis mendalam yang dapat dilakukan dengan menggunakan teknik kuantitatif maupun kualitatif dengan memakai metode ilmiah dan tidak terbatas pada bergabai jenis variabel yang dapat diukur. Teks tertulis dalam bentuk arsip surat adalah bahan yang akan dianalisis. Menurut Miles \& Huberman (dalam Sugiyono, 2017) kegiatan yang dilakukan dalam analisis data kualitatif berlangsung secara interaktif dan terus-menerus hingga tuntas. Adapun kegiatan dalam analisis data, yaitu pengumpulan data (data collection), reduksi data (data reduction), penyajian data (data display), penarikan kesimpulan dan verifikasi (conclusion drawing/verivication). Pengumpulan data secara langsung akan diambil/diminta oleh peneliti kepada pihak administrasi dari MTs Ash Shiddiqiyyah kabupaten Cirebon. Sesudah data terkumpul, akan dilakukan reduksi data dengan cara membaca dan mengidentifikasi arsip surat berdasarkan jenis surat, waktu, dan kesalahan/ketidaktepatan bentuk-bentuk kebahasaan maupun sistematika penulisan yang terdapat pada arsip surat MTs Ash Shiddiqiyyah kabupaten Cirebon. Kemudian penyajian data dilakukan dengan analisis secara mendalam untuk mendeskripsikan ketidaktepatan bentuk-bentuk bahasa dan sistematika penulisan surat pada arsip surat MTs Ash Shiddiqiyyah kabupaten Cirebon berupa uaraian kata-kata dengan menggunakan metode agih.

Menurut Sudaryanto (dalam Hasanah, 2018) metode agih ialah metode analisis data yang alat penentunya merupakan bagian bahasa yang bersangkutan itu sendiri. Tahapan yang akan dilaksanakan, yaitu menggolongkan kesalahan/ketidaktepatan bentuk-bentuk kebahasaan surat yang akan dijelaskan/dipaparkan dengan teknik lanjutan yaitu teknik ganti (substitusi) dan lesap (delisi). Teknik ganti digunakan untuk mencermati kesejajaran/keparalelan distribusi antara satuan bahasa, sementara itu teknik lesap dilakukan dengan melesapkan (melepaskan, menghilangkan, menghapuskan, mengurangi) unsur-unsur tertentu. Setelah reduksi data dan penyajian data maka tahapan selanjutnya dalam analisis data kualitatif, yaitu penarikan kesimpulan dan verifikasi. Kesimpulan diperoleh dari hasil analisis terkait ketidaktepatan bentuk-bentuk kebahasana yang terdapat pada arsip surat MTs Ash Siddiqiyyah Kabupaten Cirebon.

\section{HASIL DAN PEMBAHASAN}

\section{Hasil}

Hasil penelitian terkait surat dinas pada MTs Ash Shiddiqiyyah yang terdiri atas surat keluar dan surat masuk dari bulan Oktober s.d. Desember 2018 terdapat 20 data. Bentukbentuk kebahasaan masih terdapat ketidaktepatan penulisan dalam surat keluar dan surat masuk. Ketidaktepatan tersebut masih terlihat pada penggunaan ejaan, seperti penulisan kata yang tidak baku, penulisan kata yang dirangkai/dipisah, tanda baca (tanda garis miring, tanda seru, tanda koma, dan tanda titik), penulisan huruf kapital, huruf miring dan huruf tebal, serta singkatan. 


\section{Pembahasan}

Berikut akan dieksplanasikan temuan ketidaktepatan kebahasaan dan sistematika penulisan surat dinas dari korpus data pada penelitian ini, yaitu surat keluar dan surat masuk MTs Ash Shiddiqiyyah Kabupaten Cirebon.

1. Bentuk-bentuk Kebahasaan

Berikut ini analisis temuan mengenai bentuk-bentuk kebahasaan surat dinas. Uraian dipaparkan berdasarkan ketidaktepatan penulisan kata yang tidak baku, ketidaktepatan penulisan kata/frasa yang dirangkai/ dipisah, ketidaktepatan penggunaan tanda baca, ketidaktepatan huruf tebal dan huruf miring, dan ketidaktepatan penggunaan huruf kapital.

a. Penulisan Kata yang Tidak Baku

Terdapat beberapa ketidaktepatan penulisan kata yang tidak baku ditemukan dalam korpus data, yakni sebagai berikut.

Tabel 1 Penulisan Kata yang Tidak Baku

\begin{tabular}{clll}
\hline No. & Nomor Data & \multicolumn{1}{c}{ Kata yang Tidak Baku } & \multicolumn{1}{c}{ Pembetulan } \\
\hline 1 & Data 1 s.d. 8 & (1) Pon Pes & (1) Ponpes \\
& & (2) S.AP & (2) S.A.P. \\
2 & Data 3 & SWT & Swt \\
3 & Data 4 & Photo, infaq, samapai & Foto, infak, sampai \\
\hline
\end{tabular}

Berdasarkan tabel di atas dapat diketahui bahwa terdapat penggunaan kata yang tidak baku. Adapun kata yang tidak baku, yaitu gabungan kata Pon pes, singakatan gelar S.AP, kata photo, infaq, dan samapai. Data-data tersebut diperoleh dari arsip surat dinas yang berada di MTs Ash Shiddiqiyyah.

Pada data 1 s.d. 8 terdapat akronim Pon pes, akronim tersebut termasuk gabungan suku kata pondok pesantren. Menurut PUEBI, penulisan akronim nama diri berupa gabungan suku kata dari deret kata ditulis dengan huruf awal kapital (dalam Redaksi Cemerlang, 2018: 28). Selain akronim, terdapat singkatan gelar yang tidak depat, yaitu pada kata S.AP, seharusnya setiap unsur singkatan dibubuhkan tanda titik. Adapun pembetulannya, yaitu S.A.P.

Pada data 3, penulisan singkatan subhanahu wa ta'ala ditulis dengan huruf kapital seluruhnya. Pada kalimat salam sejahtera kami sampaikan semoga Bapak/Ibu selalu berada dalam lindungan Allah SWT, Amin!., sesuai PUEBI singkatan kata subhanahu wa ta'ala ditulis Swt. Pada data 4 terdapat penulisan kata yang tidak baku, yakni kata photo, infaq, samapai. Penulisan yang tepat dari tiga kata tersebut sesuai dengan PUEBI, yaitu foto, infak, sampai.

b. Ketidaktepatan Penulisan Kata/Frasa yang Dirangkai/ Dipisah

Ditemukan beberapa kesalahan penulisan kata depan (di) dan gabungan kata yang seharusnya dirangkai dan dipisah, berikut disajikan tabel dan pemaparannya.

Tabel 2 Ketidaktepatan Penulisan Kata/Frasa yang Dirangkai/ Dipisah

\begin{tabular}{clll}
\hline No. & Nomor Data & $\begin{array}{l}\text { Kata } \\
\text { yang Dirangkai/ Dipisah }\end{array}$ & Pembetulan \\
\hline 1 & Data $1,2,7,8,14,16$ s.d 18 & ..dibawah... & ..di bawah... \\
2 & Data 4 & $\ldots$ matapelajaran... & ..mata pelajaran... \\
3 & Data 5 \& 6 & Terimakasih & Terima kasih
\end{tabular}




\begin{tabular}{llll}
4 & Data $7 \& 8$ & $\ldots$ diatas... & $\ldots$ di atas... \\
5 & Data $7 \& 13$ & $\ldots$ di pergunakan ... & $\ldots$ dipergunakan $\ldots$ \\
6 & Data 15 & $\ldots$ di terima... & $\ldots$ diterima... \\
\hline
\end{tabular}

Ketidaktepatan penulisan kata di bawah terdapat 20 data, yaitu pada data 1, 2, 7, 8, 14, 16 s.d 18. Penulisan kata di bawah adalah penulisan yang sesuai dengan PUEBI ditulis tidak serangkai karena sebagai kata depan menunjukkan tempat dan penulisan kata di atas pun demikian. Penulisan kata di atas yang belum tepat ditemukan pada data $7 \& 8$.

Terdapat kesalahan penulisan kata mata pelajaran pada data 4, yaitu ditulis dengan menggabungkan/merangkai dua kata tersebut seharusnya dipisah karena merupakan bentuk frasa nomina. Sama halnya dengan kata mata pelajaran, kata terima kasih (data 5 \& 6) seharusnya ditulis secara terpisah. Pada data 7 s.d.1 3 dan dalam data 15 terdapat kata dibuat terdapat kata dipergunakan namun penulisan kata depan $d i$ dengan kata yang mengikutinya dalam surat ditulis secara terpisah seharusnya dirangkai karena kata depan $d i$ tersebut bukan menunjukkan tempat.

c. Ketidaktepatan Penggunaan Tanda Baca

Ditemukan penggunaan tanda baca yang tidak tepat pada surat, yaitu pemakaian tanda garis miring, tanda seru, tanda koma, dan tanda titik, tanda apostrof berikut disajikan tabel dan uraiannya.

Tabel 3 Ketidaktepatan Penggunaan Tanda Baca

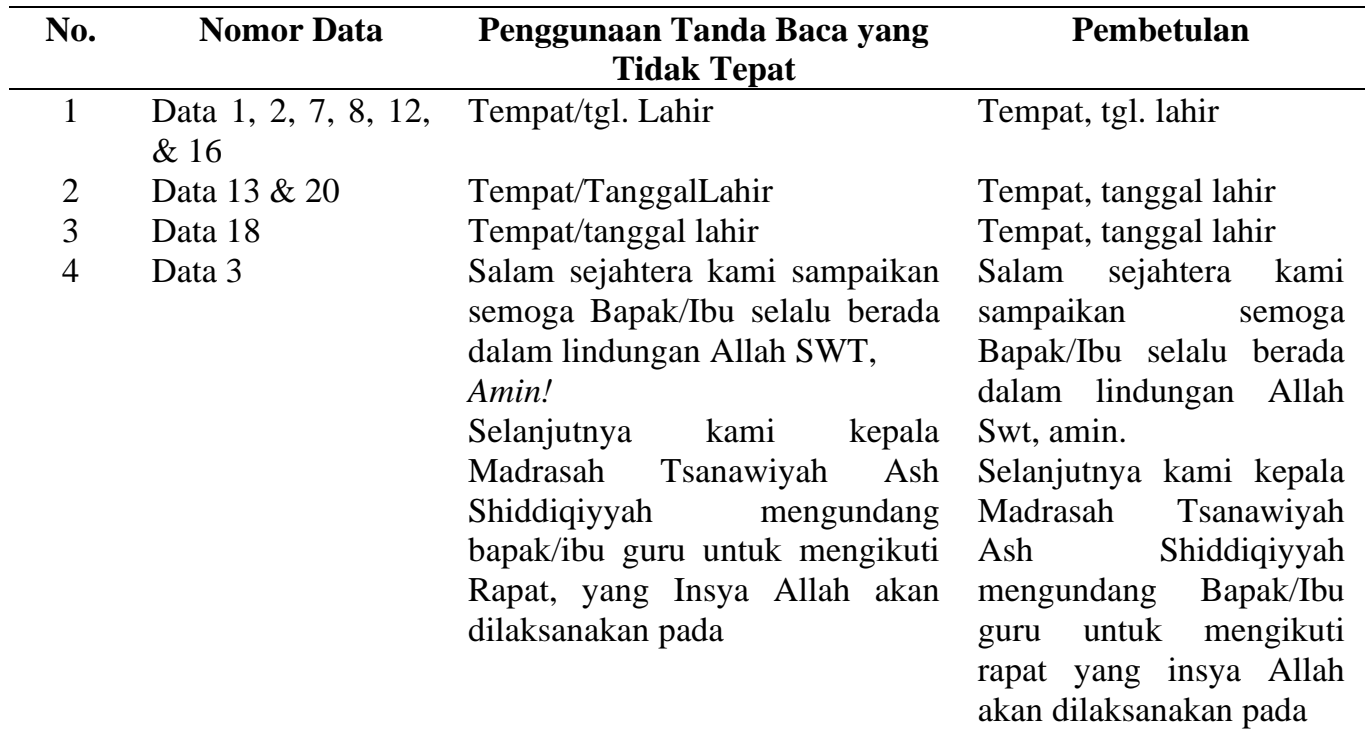


5

Data 4

6

Data 11

Data 15
1) Dengan ini kami sampaikan persiapan keuangan yang diperlukan sampai dengan akhir tahun pelajaran, dengan rincian sebagai berikut :

2) Rp. 90.000,-

Rp. 55.000,-

Rp. 90.000,-

Rp. 35.000,-

Rp. 50.000,-

Rp. 50.000,-

Rp. 40.000,-

Rp. 45.000,-

Rp. 95.000,-

Rp. 550.000,-

3) Pembayaran Biaya Akhir

Tahun (B.A.T)

dimulai sejak dikeluarkannya

surat pemberitahuan ini samapai

Tanggal 01 April 2019

MTs. Tarbiyatul Banin Kaliwadas Sumber Cirebon

Demikian surat keterangan ini di buat, untuk dapat dipergunakan sebagaimana mestinya.
1) Dengan ini kami sampaikan persiapan keuangan yang diperlukan sampai dengan akhir tahun pelajaran dengan rincian sebagai berikut:

2) Rp90.000,00

Rp55.000,00

Rp90.000,00

Rp35.000,00

Rp50.000,00

Rp50.000,00

Rp40.000,00

Rp45.000,00

Rp95.000,00

Rp550.000,00

3) Pembayaran Biaya

Akhir Tahun (BAT)

dimulai sejak

dikeluarkannya surat pemberitahuan ini sampai tanggal 1 April 2019

MTs Tarbiyatul Banin Kaliwadas Sumber Cirebon

Demikian surat keterangan ini dibuat untuk dapat dipergunakan sebagaimana mestinya.

Terdapat kesalahan pemakaian tanda baca garis miring pada data 1, 2, 7, $8,12,13,16,18, \& 20$ yaitu pada penulisan tempat, tanggal lahir. Penulisan dalam data tersebut tanda baca yang dipakai adalah garis miring, seharusnya tanda baca yang digunakan adalah tanda koma karena menyesuaikan rincian yang dituliskan. Dalam penulisan frasa tersebut pun terdapat kesalahan penggunaan huruf kapital.

Pemakaian tanda seru dan tanda koma pada data 3 tidak tepat seharusnya tidak perlu dicantumkan/dibubuhkan karena tanda seru digunakan untuk sebuah pernyataan berupa perintah atau seruan yang menggambarkan kesungguhan, ketidakpercayaan, atau pun emosi yang kuat. Pemakaian tanda koma setelah kata rapat pun tidak tepat karena pernyataan tersebut adalah satu kalimat yang utuh. Penulisan kata amin dan kata rapat pada data tersebut pun kurang tepat karena menggunakan huruf kapital pada awal kata.

Kesalahan pemakaian tanda koma pada data 4 \& 15 sama halnya dengan kesalahan penggunaan tanda koma dalam data 3. Data 4 terdapat kesalahan tanda titik yang seharusnya tidak perlu dibubuhkan setelah kata rupiah. Tanda koma dan tanda hubung yang tidak perlu setelah penulisan angka mata uang dan kesalahan tanda titik yang dipakai pada kata yang disingkat, yakni kata $B A T$, penulisan kalimat pembayaran Biaya Akhir Tahun (BAT) dimulai sejak dikeluarkannya surat pemberitahuan ini sampai Tanggal 01 April 2019. tidak tepat seharusnya tidak perlu memakai huruf tebal dan tidak perlu menggunakan miring semua, 
untuk menegaskan cukup frasa pembayaran Biaya Akhir Tahun (BAT) yang perlu ditulis dengan huruf miring. Salah satu pemakaian huruf miring, yaitu untuk menegaskan atau mengkhususkan huruf, kata, bagian kata/kelompok kata dalam kalimat. Sedangkan pada data 31 ketidaktepatan pemakaian tanda titik, yaitu setelah penulisan kata $M t s$.

Pemakaian tanda koma yang tidak tepat pada data 13 s.d. $27,35 \& 40$, sama halnya dengan data 3 . Kalimat demikian surat pindah ini kami buat agar dapat di pergunakan sebagaimana metinya (data 13 s.d. 27, \& 40) dan kalimat demikian surat keterangan ini di buat, untuk dapat dipergunakan sebagaimana mestinya. Dua kalimat tersebut masing-masing kalimat merupakan satu kalimat yang utuh (satu kalusa) sehingga dalam penulisannya tidak perlu membubuhkan tanda koma.

d. Ketidaktepatan Huruf Tebal dan Huruf Miring

Ketidaktepatan penulisan huruf tebal dan huruf miring banyak ditemukan dalam surat berikut paparannya.

Tabel 4 Ketidaktepatan Huruf Tebal dan Huruf Miring

\begin{tabular}{|c|c|c|c|}
\hline No. & Nomor Data & $\begin{array}{c}\text { Penggunaan } \\
\text { Huruf Tebal dan Huruf Miring yang } \\
\text { Tidak Tepat }\end{array}$ & n \\
\hline 1 & Data 1 s.d. 8 & Rasmita Hadi Susanto, S.AP. & Rasmita Hadi Susa \\
\hline 2 & Data & $\begin{array}{l}\text { (1) Nama: MOHAMMAD SHOBRI } \\
\text { (2) } \ldots \text { SMP } \quad \boldsymbol{N} \quad 2 \quad \text { Klenganan } \\
\\
\text { Cirebon... } \\
\text { (3) Nama: } \text { AHMAD SUSANTO }\end{array}$ & $\begin{array}{l}\text { (1) Nama: Mohammad Shobri } \\
\text { (2) ..SMP N } 2 \text { Klenganan di } \\
\text { Cirebon... } \\
\text { (3) Nama: Ahmad Susanto }\end{array}$ \\
\hline 3 & Data 3 & $\begin{array}{l}\text { Rapat Persiapan Penilaian Akhir } \\
\text { Semester TP. 2018/2019 }\end{array}$ & $\begin{array}{l}\text { Rapat Persiapan Penilaian Akhir } \\
\text { Semester T.P. 2018/2019 }\end{array}$ \\
\hline 4 & Data 2 & $\begin{array}{l}\text { (1) Nama: } \boldsymbol{A D E N A} \boldsymbol{B A G} \boldsymbol{B} \boldsymbol{S} \boldsymbol{S A J I W O} \\
\text { (2) ..SMP N 1 Juntinyuat di } \\
\text { Indramayu... } \\
\text { (3) Nama: } \boldsymbol{A N A}(\text { data } 22)\end{array}$ & $\begin{array}{l}\text { (1) Nama: Adena Bagus Sajiwo } \\
\text { (2) ..SMP N 1 Juntinyuat di } \\
\text { Indramayu... } \\
\text { (3) Nama : Ana }\end{array}$ \\
\hline 5 & Data 4 & $\begin{array}{l}\text { (1) ...Januari s/d April 2019 } \\
\text { (2) Jumlah Rp. 550.000.- }\end{array}$ & $\begin{array}{l}\text { (1) } \ldots \text { Januari s.d. April } 2019 \\
\text { (2) Jumlah Rp550.000,- }\end{array}$ \\
\hline 6 & Data $7 \& 8$ & $\ldots B A I K \ldots$ & ...baik. \\
\hline 7 & $\mathrm{Da}$ & $\begin{array}{l}\text { (1) Nama: AGUS SALIM } \\
\text { (2) Nama: WARTIAH (data 14) } \\
\text { (3) (...MTs Al Ikhlas Mayung di } \\
\text { Cirebon }\end{array}$ & $\begin{array}{l}\text { (1) Nama : Agus Salim } \\
\text { (2) Nama: Wartiah } \\
\text { (3) ..MTs Al Ikhlas Mayung di } \\
\text { Cirebon }\end{array}$ \\
\hline 19 & Data & $\begin{array}{l}\text { (1) Assalamu'alaikum } \boldsymbol{W r} \text {. Wb } \\
\text { (2) Nama Siswa: MOHAMMAD } \\
\text { RIZKY IMANSYAH } \\
\text { (3) Wassalamu'alaikm } \boldsymbol{W r} \text {. Wb } \\
\text { (4) } \text { Hj. IJAH BAHIJAH, S.Ag, MA }\end{array}$ & $\begin{array}{l}\text { (1) Assalamualaikum W. W. } \\
\text { (2) Nama siswa : Mohammad } \\
\text { Rizky Imansyah } \\
\text { (3) Wassalamualaikum W. W. } \\
\text { (4) Hj. Ijah Bahijah, S.Ag, M.A. }\end{array}$ \\
\hline 20 & Data 12 & $\begin{array}{l}\text { (1) Nama : AGUS SALIM } \\
\text { (2) ROKIMI, S.Ag }\end{array}$ & $\begin{array}{l}\text { (1) Nama : Agus Salim } \\
\text { (2) Rokimi, S.Ag. }\end{array}$ \\
\hline 21 & Data 13 & $\begin{array}{l}\text { (1) Nama : M. HUSNUL BADRI } \\
\text { (2) ADE M. SIKHABUDIN, S.Ag, } \\
\text { M.M }\end{array}$ & $\begin{array}{l}\text { (1) Nama: M. Husnul Badri } \\
\text { (2) Ade M. Sikhabudin, S.Ag, } \\
\text { M.M. }\end{array}$ \\
\hline 22 & Data & $\begin{array}{l}\text { (1) DRS. H. MASYKUR } \\
\text { (2) Nama : REGGY PRANANDA }\end{array}$ & $\begin{array}{l}\text { (1) Drs. H. Masykur } \\
\text { (2) Nama : Reggy Prananda }\end{array}$ \\
\hline 23 & Data 1 & $\begin{array}{l}\text { (1) ..SMP AS-salafiyah Krangkeng } \\
\text { (2) Nama : ADKMAD NOVAL } \\
\text { (3) MUKROMIN, S.Pd.I }\end{array}$ & $\begin{array}{l}\text { (1) ..SMP As-Salafiyah } \\
\text { Krangkeng... } \\
\text { (2) Nama : Adkmad Noval } \\
\text { (3) Mukromin, S.Pd.I. }\end{array}$ \\
\hline 24 & & H. DEDI SUKANDI, S.Pd & H. Dedi Sukandi, S.Pd. \\
\hline 25 & Data 17 & $\begin{array}{l}\text { (1) Nama : MOHAMAD RAMLI } \\
\text { HIDAYAT }\end{array}$ & $\begin{array}{l}\text { (1) Nama : Mohamad Ramli } \\
\text { Hidayat }\end{array}$ \\
\hline
\end{tabular}




$\begin{array}{ll}26 & \text { Data } 18 \\ 27 & \text { Data } 19\end{array}$

(2) Maftukhin, S. Th.I

(1) Nama : ZAHROTUL WAHIDAH

(2) H. KAMALI, MA

(1) Nama : DAFFA AHMAD YUSUF (2) Drs. WAHYUDIN, M. Ag.
(2) Maftukhin, S. Th.I.

(1) Nama : Zahrotul Wahidah

(2) H. KAMALI, M.A.

(1) Nama : Daffa Ahmad Yusuf

(2) Drs. Wahyudin, M. Ag.

Huruf tebal pada penulisan nama orang dalam data 1 s.d. 8 tidak tepat karena huruf tebal tidak digunakan untuk penulisan nama orang dan tidak tepat dalam penulisan singkatan gelar. Penggunaan huruf tebal dan miring pada data 1 \& 2 tidak tepat karena penulisan nama orang ditulis dengan huruf kapital, huruf miring, dan huruf tebal. Penulisan nama tempat pun tidak tepat karena dalam surat ditulis dengan huruf tebal dan miring. Pemakaian huruf tebal dan huruf miring pada data 4 tidak tepat, yaitu pada penulisan Januari s/d April 2019, penulisan singkatan kata sama dengan pun tidak tepat, dan penulisan jumlah Rp. 550.000,tidak tepat karena menggunakan huruf tebal, serta penulisan rupiah yang masih salah.

Adapun pada data $3 \& 11$ penulisan kata salam tidak tepat. Penulisan kata salam tersebut bukan bentuk baku dan seharusnya tidak perlu ditulis dengan huruf tebal dan huruf miring. Pada data 11 s.d. 19 kesalahan yang tertulis adalah penggunaan huruf kapital semua dan huruf tebal dalam penulisan nama orang. Dalam data 11 s.d. 13,15 s.d. 18 selain ketidaktepatan penggunaan huruf kapital dan huruf tebal terdapat kesalahan penulisan singkatan gelar. Penulisan kata yang disingkat seharusnya diakhiri dengan tanda titik. Pada data 15 selain kesalahan penulisan nama orang dan gelar terdapat penulisan nama tempat yang seharusnya tidak ditulis dengan huruf tebal.

e. Ketidaktepatan Penggunaan Huruf Kapital

Berikut temuan penggunaan huruf kapital yang tidak tepat.

Tabel 5 Ketidaktepatan Penggunaan Huruf Kapital

\begin{tabular}{|c|c|c|c|}
\hline No. & Nomor Data & $\begin{array}{c}\text { Penggunaan } \\
\text { Huruf Kapital yang Tidak Tepat }\end{array}$ & Pembetulan \\
\hline 1 & Data $1,2, \& 7$ & Tempat/Tgl. Lahir & Tempat, tanggal lahir \\
\hline 2 & Data 1 & Jenis Kelamin : Laki-Laki & Jenis kelamin : Laki-laki \\
\hline 3 & Data 2 & Tingkat/Kelas : VII (Tujuh) & Tingkat/kelas : VII (tujuh) \\
\hline 4 & Data 7 & Tingkat/Kelas : VIII (Delapan) & $\begin{array}{l}\text { Tingkat/kelas } \quad: \quad \text { VIII } \\
\text { (delapan) }\end{array}$ \\
\hline 5 & Data 8 & Tingkat/Kelas : IX (Sembilan) & Tingkat/kelas : IX (sembilan) \\
\hline 6 & Data $1 \& 2$ & $\begin{array}{ll}\text { Demikian } & \text { Permohonan } \\
\text { Rekomendasi... } & \end{array}$ & $\begin{array}{l}\text { Demikian permohonan } \\
\text { rekomendasi... }\end{array}$ \\
\hline 7 & Data 3 & ...Rapat,... & ...rapat... \\
\hline \multirow[t]{4}{*}{8} & Data 4 & $\begin{array}{ll}\text { (1) } & \ldots \text { Tahun Pelajaran... } \\
\text { (2) } & \ldots \text { Mulai Bulan... } \\
\text { (3) } & \ldots \text { Pelajaran... } \\
\text { (4) } & \ldots \text { Pemantapan... } \\
\text { (5) } & \ldots \text { Nasional... } \\
\text { (6) } & \ldots \text { (Pengayaan) }\end{array}$ & $\begin{array}{l}\text { (1) } \ldots \text { tahun pelajaran... } \\
\text { (2) } \ldots \text { mulai bulan... } \\
\text { (3) } \\
\text { (4) } \ldots \text { pemantapan ... } \\
\text { (5) } \ldots \text { nasional... } \\
\text { (6) } \ldots \text { (pengayaan) }\end{array}$ \\
\hline & & $\begin{array}{l}\text { (7) Buku Panduan Latihan Ujian } \\
\text { Nasional Dan Penyelesaiannya }\end{array}$ & $\begin{array}{l}\text { (7) Buku Panduan Latihan } \\
\text { Ujian Nasional dan }\end{array}$ \\
\hline & & (8) Tanda lencana dan Pin & penyelesaiannya \\
\hline & & $\begin{array}{ll} & \text { Almamater } \\
\text { (9) } \ldots \text { pemberitahuan ini samapai } \\
\text { Tanggal 01 April } 2019\end{array}$ & $\begin{array}{l}\text { (8) Tanda lencana dan pin } \\
\text { almamater }\end{array}$ \\
\hline
\end{tabular}


(10) Biaya Perpisahan

(11) Demikian Surat pemberitahuan ini...

$9 \quad$ Data $5 \& 6$

10 Data $7 \& 8$

11 Data 40
Kami Sampaikan...

...Peserta Didik...

...Tahun Pelajaran...

H. ASEP DARMAWAN, M.Pd
(9) ...pemberitahuan ini samapai tanggal 1 April 2019

(10) Biaya perpisahan

(11) Demikian surat pemberitahuan ini...

Kami sampaikan...

...peserta didik...

...tahun pelajaran...

H. Asep Darmawan, M.Pd.

Berdasarkan tabel di atas dapat diketahui pada data 1, 2, 7, \& 8 terdapat penggunaan huruf kapital, yakni pada frasa tempat, tanggal lahir. Huruf kapital pada frasa tanggal lahir yang dituliskan $\mathrm{Tgl}$. Lahir tidak tepat karena frasa tersebut bukanlah awal kata pada frasa tersebut. Dalam data 1 penulisan huruf kapital yang digunakan pada dua gabungan kata tidak tepat, yaitu kata jenis kelamin dan lakilaki akan tepat jika kata kedua pada masing-masing gabungan kata tersebut menggunakan huruf kecil. Ketidaktepatan pada kata Tingkat/kelas: VII (tujuh) dalam data 2, kata Tingkat/kelas : VIII (delapan) (data 7), yakni pada kata kelas yang seharusnya huruf pertama pada kata tersebut tidak diawali dengan huruf kapital, demikian juga pada kata tujuh, depalan, dan sembilan yang dituliskan dalam tanda kurung huruf pertama tidak perlu menggunakan huruf kapital.

Pada kalimat demikan permohonan rekomendasi ini kami buat, semoga Bapak dapat mengabulkannya dalam data $1 \& 2$ terdapat pemakaian huruf kapital yang tidak tepat yaitu frasa permohonan rekomendasi seharusnya ditulis dengan huruf kecil semua. Pada data 3 terdapat kalimat selanjutnya kami kepala Madrasah Tsanawiyah Ash Shiddiqiyyah mengundang bapak/ibu guru untuk mengikuti rapat, penulisan kata rapat tidak tepat karena ditulis dengan huruf kapital pada awal kata seharusnya menggunakan huruf kecil. Adapun dalam data 4 banyak kesalahan pemakaian huruf kapital pada kalimat Dalam rangka mempersiapkan pemantapan putra/putri bapak/ibu ke jenjang Ujian Nasional Berbasis Komputer (UNBK) tahun pelajaran 2018/2019. Kami telah mengadakan tamabahan pelajaran sekolah (pengayaan) mulai bulan januari s.d. April 2019. Dengan ini kami sampaikan persiapan keuangan yang diperlukan sampai dengan akhir tahun pelajaran dengan rincian sebagai berikut, yakni pada frasa tahun pelajaran, frasa mulai bulan, dan kata pelajaran seharusnya ditulis dengan huruf kecil semua. Selain ketidaktepatan huruf kapital pada kalimat tersebut ditemukan huruf kapital, yaitu pada kata pemantapan, nasional, dan pengayaan dalam kalimat Biaya pemantapan mata pelajaran ujian nasional (pengayaan), konjungsi dan \& kata penyelesaiannya pada frasa Buku Panduan Latihan Ujian dan Penyelesaiannya, gabungan kata pin almamater dalam frasa Tanda lencana dan pin almamater, kata perpisahan pada kalimat Biaya Perpisahan, kata tanggal pada kalimat pembayaran Biaya Akhir Tahun (BAT) dimulai sejak dikeluarkannya surat pemberitahuan ini sampai tanggal 01 April 2019, dan kata surat pada kalimat Demikian surat ini kami sampaikan, atas perhatian dan kerja samanya kami ucapkan terima kasih.

Sama halnya dengan data 4 , dalam data 5 \& 6, kata sampaikan pada kalimat Kami sampaikan dengan hormat agar dapat bisa ditindak lanjuti seharusnya tidak perlu ditulis dengan huruf kapital pada awal kata. Selain kesalahan huruf kapital pada kalimat tersebut terdapat kata yang keliru, yakni kata 
bias. Kata bias tersebut dapat dilesapkan agar tidak teradapat kesalahan penulisan kata/pemilihan kata. Terdapat dua kesalahan pemakaian huruf kapital pada gabungan kata peserta didik dan gabungan kata tahun pelajaran dalam data $7 \&$ 8. Adapun pada data 40 terdapat kesalahan penggunaan huruf kapital dalam penulisan nama orang.

\section{SIMPULAN}

Ketidaktepatan bentuk-bentuk kebahasaan dalam surat dinas yang terdiri atas surat keluar dan surat masuk yang ditemukan, yakni sejumlah 15 penulisan kata yang tidak baku berupa kata dan singkatan kata, enam kesalahan penulisan kata/frasa yang seharusnya dirangkai/ dipisah, kesalahan penggunaan tanda baca (9 tanda garis miring, satu tanda seru, 12 tanda koma, dan 13 tanda titik), 25 kesalahan penggunaan huruf miring dan huruf tebal, 38 kesalahan penggunaan penulisan huruf kapital.

\section{DAFTAR PUSTAKA}

Alek \& H. Achmad. (2011). Bahasa Indonesia untuk perguruan tinggi. Jakarta: Prenada Media Grup.

Darma, A. Y. \& Kosasih. (2012). Menulis surat dinas lengkap. Bandung: CV. Yrama Widya.

Darmastuti, F. D. (2009). Analisis Kesalahan Berbahasa dalam Surat Dinas Kantor Kelurahan Ngolodono Karangdowo Klaten. http://eprints.ums.ac.id/4510/1/A310050223.pdf

Emzir. (2012). Metodologi penelitian kualitatif analisis data. Jakarta: Rajawali Pers.

Gunawan, I. (2015). Metode penelitian kualitatif teori dan praktik. Jakarta: PT Bumi Aksara.

Harumi, E. (2011). Analisis kesalahan berbahasa indonesia kajian dalam surat dinas. Surakarta: Yuma Pustaka.

Hasanah, N. (2018). Analisis Kesalahan Gramatika Bahasa Indonesia dalam Surat Resmi di Kantor Desa Mamben Lauk. Jurnal Linguistik, 3 (1), https:/jurnal.uns.ac.id/pj1/article/download/2064/15864

Moleong, L. J. (2013). Metode penelitian kualitatif. Bandung: PT Remaja Rosdakarya.

Pujiono, S. (2013). Terampil menulis cara mudah dan praktis dalam menulis. Yogyakarta: Graha Ilmu.

Putrayasa, I. B. (2007). Kalimat efektif. Bandung: Refika Aditama.

Redaksi Cemerlang. (2018). Pedoman umum ejaan bahasa indonesia \& sastra Indonesia. Tangerang Selatan: Cemerlang.

Sugiyono. (2017). Metode penelitian kualitatif. Bandung: Alfabeta. 
Sunarti, S. (2011). Kesalahan Kebahasaan dalam Surat Dinas di Kantor Pengadilan Negeri Wonosobo Kabupaten Wonosobo Tahun 2011. http://download.portalgaruda.org/article.php? article $=128892 \&$ val $=609$

Suprapto, (2014). Penuntun praktis surat menyurat dinas resmi bahasa Indonesia. Bandung: CV. Mandar Maju.

Soedjito. (2018). Surat menyurat resmi bahasa Indonesia. Bandung: PT Remaja Rosdakarya.

Yolanda, C. (2017). Penggunaan Bahasa Indonesia pada Surat Dinas Di Kantor Kecamatan Mesuji Kabupaten Mesuji Serta Implikasinya Terhadap Pembelajaran Menulis di Sekolah.http://digilib.unila.ac.id/26924/20/SKRIPSI\%20TANPA\%20 BAB\%2OPEMBAHASAN.pdf

Yulianto, E. (2016). Kesalahan Penulisan Tata Bahasa pada Surat Resmi Organisasi Mahasiswa. DEIKSIS, 8(03), 238-246. 